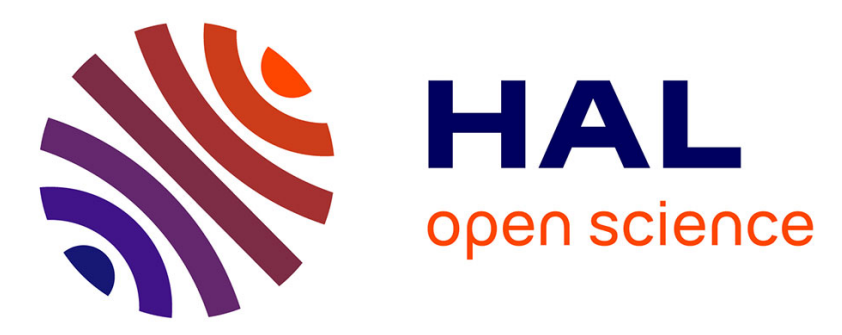

\title{
Concerning the plausibility of the findings reported in 'Prenatal exposure to glycol ethers and cryptorchidism and hypospadias a nested case-control study' by Smet and Kelsey authors' response
}

Charline Warembourg, Luc Multigner, Ronan Garlantezec

\section{To cite this version:}

Charline Warembourg, Luc Multigner, Ronan Garlantezec. Concerning the plausibility of the findings reported in 'Prenatal exposure to glycol ethers and cryptorchidism and hypospadias a nested casecontrol study' by Smet and Kelsey authors' response. Occupational and Environmental Medicine, 2018, 75 (12), pp.917-918. 10.1136/oemed-2018-105393 . hal-01888874

HAL Id: hal-01888874

https://hal-univ-rennes1.archives-ouvertes.fr/hal-01888874

Submitted on 8 Nov 2018

HAL is a multi-disciplinary open access archive for the deposit and dissemination of scientific research documents, whether they are published or not. The documents may come from teaching and research institutions in France or abroad, or from public or private research centers.
L'archive ouverte pluridisciplinaire HAL, est destinée au dépôt et à la diffusion de documents scientifiques de niveau recherche, publiés ou non, émanant des établissements d'enseignement et de recherche français ou étrangers, des laboratoires publics ou privés. 
Concerning the plausibility of the findings reported in 'Prenatal exposure to glycol ethers and cryptorchidism and hypospadias a nested case-control study' by Smet and Kelsey: authors' response

Reply Letter to Smet and Kelsey: Concerning the plausibility of the findings reported in "Prenatal exposure to glycol ethers and cryptorchidism and hypospadias: a nested case-control study", Warembourg et al, Occup Environ Med 2018;75:59-65

Warembourg $C^{1}$, Multigner $L^{1}$, and Garlantézec $R^{1,2}$.

${ }^{1}$ Univ Rennes, Inserm, EHESP, Irset (Institut de recherche en santé, environnement et travail) UMR_S 1085, F-35000, Rennes, France

${ }^{2}$ Service de Santé Publique et d'Epidemiologie, Centre Hospitalo-Universitaire de Rennes, F35033, Rennes, France

Corresponding author:

Full name: Dr Charline Warembourg

Postal address: UMR Inserm 1085 Irset - 9 Avenue du Prof. Léon Bernard, 35000 Rennes, France

Email: charline.warembourg@gmail.com

\section{Conflict of interest:}

None to declare 
We read with attention the letter from Smet and Kelsey discussing the interpretation of our findings. Smet and Kelsey ${ }^{1}$ questioned the validity of our findings regarding the high detection rate of methoxyacetic acid (MAA) we observed in our population despite the restriction in use of its precursors in Europe. First, human biomonitoring studies on glycol ether (GE) exposure in the non-occupational context are very few but other recent studies have also reported a high detection rate of MAA in the European general population in 2007-2009: MAA was detected in $99 \%$ and $100 \%$ of urine samples with a median concentration of $0.05 \mathrm{mg} / \mathrm{L}$ and $0.11 \mathrm{mg} / \mathrm{L}$ in a German $^{2}$ and a French population, ${ }^{3}$ respectively. Second, regarding the sources of exposure to diethylene glycol monomethyl ether (DEGME) and triethylene glycol monomethyl ether (TEGME) as potential precursors of MAA detected in our study population, the period of recruitment (2002-2006) of the pregnant women included in our study should be considered. The references given by Smet and Kelsey are not reflecting the usage at the time of the study. Indeed, DEGME is no longer used in consumer products since 2010 (at least without a concentration exceeding $0.1 \%$ by weight) but was previously used in paints and cleaning agents as assessed by the European chemicals agency ${ }^{4}$ and the French agency for environmental and occupational safety. ${ }^{5}$ Nowadays, as Smet et al said, TEGME is mainly use in hydraulic fluids but the reference they cited reported additional usages in consumer products such as in coatings, adhesives or inks, and that 'other release to the environment is likely to occur from [...] indoor use (eg, machine wash liquids/detergents, automotive care products, paints and coating or adhesives, fragrances and air fresheners). ${ }^{6}$ Finally, we would like to highlight that each of these two GE (DEGME and TEGME) are manufactured or imported in 10000 to 100000 tons per annum in Europe. ${ }^{6,7}$ Smet and Kelsey consider that the MAA we measured could not come from GE exposures; however, they did not provide any alternative exposure source that may explain the detection of MAA in urine. To our knowledge, there are no other compounds than GE as precursors of MAA. 
As a second limitation, Smet and Kelsey indicate that the prevalence of male genital anomalies in our study is low. As we acknowledged in the discussion section of our article, the prevalence of male genital anomalies (especially cryptorchidism) is highly dependent of its definition (ie, the inclusion or exclusion of minor cases). ${ }^{8}$ In our study, $1.9 \%$ of boys were diagnosed with cryptorchidism at birth (excluding cases with testis in high scrotal position) and $0.4 \%$ with hypospadias. Comparing with data published by Boisen et al (original reference used by Skakkebaek), the prevalence of cryptorchidism after exclusion of cases with testis in high scrotal position is similar to the one we reported: $1.2 \%$ in Finland and $2.1 \%$ in Denmark. For hypospadias, prevalence in the EDEN (Etude des déterminants pré et postnatals du développement et de la santé de l'enfant) and PELAGIE (Perturbateurs endocriniens: étude longitudinale sur les anomalies de la grossesse, l'infertilité et l'enfance) cohorts are in accordance with existing prevalence data. ${ }^{9}$ In any case, it is known that the toxic effect of GE is caused by their alkox acid metabolites-in particular, MAA which is a known testicular toxicant-and ignoring the parent compound did not question our conclusion. Additional human biomonitoring studies would be important to assess current exposure level and evaluate the source of GE metabolites. Such studies will help to correctly perform a risk assessment evaluation and potentially provide recommendations to limit exposure of pregnant women. In addition, even if the European population is no longer being exposed to MAA, our results are of concern for non-European countries where precursors of MAA are not regulated. 


\section{References:}

1. Smet K, Kelsey J. Plausibility of the findings reported in 'Prenatal exposure to glycol ethers and cryptorchidism and hypospadias: a nested case- control study. Occup Environ Med 2018. doi:10.1136/oemed-2018-105346. [Epub ahead of print 14 Sept 2018].

2. Fromme $\mathrm{H}$, Nitschke L, Boehmer $\mathrm{S}$, et al. Exposure of German residents to ethylene and propylene glycol ethers in general and after cleaning scenarios. Chemosphere 2013;90:271421.

3. Nisse C, Labat L, Thomas J, et al. Caractérisation de l'exposition aux éthers de glycol d'un échantillon de population générale du Nord-Pas-de-Calais par biométrologie urinaire. Toxicol Anal Clin 2017;29:418-40.

4. European Chemicals Agency. Annex XVII to REACH - Conditions of restriction of DEGME. https://echa.europa. eu/documents/10162/c0b7baea-d2d6-4fa5-86b8- c322ab573d8f (accessed 23 Jul 2018).

5. AFSSET, 2003. Les éthers de glycol - Synthèse des connaissances sur les expositions de la population générale en France, 2008 https://www.anses.fr/fr/ system/files/CHIM2003et0016Ra-3.pdf (accessed 23 Jul 2018).

6. European Chemicals Agency. Brief profile for TEGME. https://echa.europa.eu/fr/briefprofile/-/briefprofile/100. 003.602 (accessed 23 Jul 2018).

7. European Chemicals Agency. Brief profile for DEGME. https://echa.europa.eu/fr/substanceinformation/-/ substanceinfo/100.003.551 (accessed 23 Jul 2018).

8. Boisen KA, Kaleva M, Main KM, et al. Difference in prevalence of congenital cryptorchidism in infants between two Nordic countries. Lancet 2004;363:1264-9.

9. Springer A, van den Heijkant M, Baumann S. Worldwide prevalence of hypospadias. J Pediatr Urol 2016;12:152. e1-7 